\title{
Purification and Some Properties of Protease I Having Transfer Action from Streptomyces griseus var. alcalophilus
}

\author{
Tetsuo Muro, Takumi Murakami,* Yoshio Tominaga, \\ Tai TOKuYama* and Shigetaka OKadA \\ Osaka Municipal Technical Research Institute, 6-50 Morinomiya 1-chome, Joto-ku, Osaka 536, Japan \\ * Faculty of Engineering, Kansai University, Yamate-cho, Suita-shi, Osaka 564, Japan \\ Received May 2, 1990
}

\begin{abstract}
Streptomyces griseus var. alcalophilus was selected because it secreted a unique protease (protease I) that catalyzed the transfer reaction forming the hydroxamic acids of various amino acids. Protease I was purified to the electrophoretically homogeneous state and an activity of more than 125-fold that of the culture broth. The molecular weight of the enzyme was estimated to be 25,000 by gel filtration. The enzyme was most active in neutral $\mathrm{pH}$ for the transfer reaction forming phenylalanine hydroxamic acid, although for the hydrolytic reaction with casein as substrate it was most active in alkaline $\mathrm{pH}$. The enzyme was inhibited by diisopropylfluorophosphate. Protease I catalyzed the transfer reaction synthesizing the hydroxamic acids of hydrophobic, acidic, basic, and small aliphatic amino acids such as Phe, Tyr, Leu, Asp, Glu, Arg, Lys, Ala, and Gly. These results indicate that protease I has broad donor specificity. It is also considered that protease $I$ is a unique enzyme with transfer activity, and distinct from the alkalophilic proteinase reported previously [Yamamoto et al., Agric. Biol. Chem., $38,37(1974)]$.
\end{abstract}

Proteases such as trypsin, papain, and $\alpha$ chymotrypsin catalyze peptide bond hydrolysis via an acyl-enzyme intermediate. Although the equilibrium of the reaction overwhelmingly favors hydrolysis under physiological conditions, the reaction can be reversed by choosing appropriate conditions so that peptide bonds can be synthesized with a protease as catalyst. Since Bergmann and colleagues reported enzymatic peptide synthesis, ${ }^{1,2)}$ many papers have reported the potential of proteases as catalysts for peptide synthesis. ${ }^{3-8)}$ However, proteases used for peptide synthesis are enzymes obtained mainly from animals and plants, and the synthetic reaction is strongly dependent on the substrate specificities of the proteases used. Therefore, to synthesize various peptides, it is useful to obtain proteases that strongly catalyze the transfer reaction with a broad donor (or acceptor) specificity.

We screened for an enzyme effectively catalyzing the transfer reaction of amino acids from various commercial enzymes. An enzyme (protease I) having a strong transfer activity was found in the crude enzyme prepared from Streptomyces griseus var. alcalophilus. Protease I catalyzed the transfer reaction forming hydroxamic acids of various amino acids from mixtures of amino acid esters and hydroxylamine. This study deals with the purification and some properties of protease I having transfer action from $S$. griseus var. alcalophilus.

\section{Materials and Methods}

Materials. Synthetic peptides and esters of various amino acids (or peptides) were purchased from the Peptide Institute, Inc. Osaka, Sigma Chemical Company, and Bachem Feinchemikalien AG. Monoiodo acetic acid, $p$ chloromercuribenzoate, and dithiothreitol were purchased from Nacalai Tesque, Inc. All other inhibitors were obtained from Sigma Chemical Company. All other chemicals used were of reagent grade.

Screening of an enzyme having transfer action. Enzymes having transfer action were screened from crude preparations of various commercial enzymes. Their transfer activities forming phenylalanine hydroxamic acid and proteolytic activities were measured at $\mathrm{pH} 7.0$ and $\mathrm{pH}$ 7.2 , respectively. 
Assay of transfer activity. The transfer activity (TA) was assayed by a modification of the method of McDonald $e t$ al. ${ }^{9)}$ The assay medium was assembled by combining $0.1 \mathrm{ml}$ of $2 \mathrm{M} \mathrm{NH}{ }_{2} \mathrm{OH}$ (prepared fresh and adjusted to $\mathrm{pH} 7.0$ ), $0.1 \mathrm{ml}$ of $0.2 \mathrm{M}$ phosphate buffer $(\mathrm{pH} 7.0)$, and $0.1 \mathrm{ml}$ of enzyme solution. After the mixture was kept at $40^{\circ} \mathrm{C}$ for $2 \mathrm{~min}$, the reaction was started by adding $0.1 \mathrm{ml}$ of $0.4 \mathrm{M}$ phenylalanine ethyl ester (Phe-OEt) in $0.1 \mathrm{M}$ phosphate buffer, $\mathrm{pH}$ 7.0. After an appropriate time of incubation at $40^{\circ} \mathrm{C}$, the reaction was stopped by the addition of $0.4 \mathrm{ml}$ of $20 \%$ trichloroacetic acid (TCA), followed by $0.5 \mathrm{ml}$ of $5 \% \mathrm{FeCl}_{3} \cdot 6 \mathrm{H}_{2} \mathrm{O}$ in $0.1 \mathrm{M} \mathrm{HCl}$. The volume was adjusted to $2 \mathrm{ml}$ with water, and the absorbance at $500 \mathrm{~nm}$ was measured with a Shimadzu UV-210A spectrophotometer. The zero time value was obtained by adding TCA and $\mathrm{FeCl}_{3} \cdot 6 \mathrm{H}_{2} \mathrm{O}$ before the enzyme, after Phe-OEt and $\mathrm{NH}_{2} \mathrm{OH}$ solutions were incubated without enzyme. One unit is defined as the amount of enzyme that catalyzes the formation of $1 \mu \mathrm{mol}$ of phenylalanine hydroxamic acid (Phe-NHOH) per min under the conditions of the assay.

Assay of proteolytic activity. The proteolytic activity (PA) was assayed by the method of Yamamoto et al. ${ }^{10,11)}$ A half milliliter of enzyme solution was added to $3.0 \mathrm{ml}$

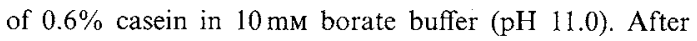
$10 \mathrm{~min}$ of incubation at $30^{\circ} \mathrm{C}$, the reaction was stopped by the addition of TCA mixture solution $(3.2 \mathrm{ml})$ containing $0.11 \mathrm{M} \mathrm{TCA}, 0.22 \mathrm{M}$ sodium acetate, and $0.33 \mathrm{M}$ acetic acid. The absorbance of the filtrate was measured at $275 \mathrm{~nm}$ using a Shimadzu UV-210A spectrophotometer. One unit is defined as the amount of enzyme that released $1 \mu \mathrm{mol}$ of tyrosine equivalent per min from the substrate.

Assay of the hydrolytic activity of the enzyme against various peptides and amino acid esters. The reaction system for identification is almost the same as one of Yamamoto et $a l{ }^{10)}$ The mixture of the enzyme and each substrate was incubated in $0.05 \mathrm{~m}$ borate buffer ( $\mathrm{pH} \mathrm{10.0)}$. The hydrolytic products were identified by thin layer chromatography (TLC). The chromatography was done with TLC plates silica gel 60 (Kieselgel 60) purchased from Merck Japan Ltd., by the ascending method, using phenol and water $(3: 1)$ as the solvent system.

For measurements, $0.5 \mathrm{ml}$ of the enzyme solution was added to $0.5 \mathrm{ml}$ of peptide solution in $0.05 \mathrm{M}$ borate buffer ( $\mathrm{pH} 10.0$ ) containing $10 \%$ dimethyl sulfoxide. After an appropriate time of incubation at $40^{\circ} \mathrm{C}$, the amino groups liberated in the reaction mixture were measured by the method of Yemm and Cocking. ${ }^{12)}$

The hydrolytic activity of the enzyme against amino acid esters was assayed by the method of Roberts. ${ }^{13)} \mathrm{A}$ half milliliter of enzyme solution was added $0.5 \mathrm{ml}$ of various amino acid esters in $0.1 \mathrm{M}$ phosphate buffer ( $\mathrm{pH} 7$ ). After an appropriate time of incubation at $40^{\circ} \mathrm{C}, 0.6 \mathrm{ml}$ of $1 \mathrm{M}$ alkaline hydroxylamine was added to $0.1 \mathrm{ml}$ of the reaction mixture. After $20-30 \mathrm{~min}, 0.4 \mathrm{ml}$ each of $4 \mathrm{~N} \mathrm{HCl}, 18 \%$ TCA, and $10 \% \mathrm{FeCl}_{3} \cdot 6 \mathrm{H}_{2} \mathrm{O}$ were added to the above solution. The amounts of ester remained were measured by the colorimetric method based on the formation of a ferric complex from the hydroxamic acid resulting in the reaction of an ester with alkaline hydroxylamine.

The hydrolytic activity of the enzyme against amides of peptides was assayed by measurement of the amounts of ammonia liberated, by the method of Snell and Snell. ${ }^{14)}$

Measurement of protein. Protein was measured spectrophotometrically by the absorbance at $280 \mathrm{~nm}$ using a Shimadzu UV-210A spectrophotometer. In the purified enzyme solution, the molar concentration of the enzyme was measured by using an absorbance at $280 \mathrm{~nm}$ for $1 \%$ solution in a $1-\mathrm{cm}$ cell $\left(E_{280}^{1 \%}\right)$ of 10.3 and a molecular weight of 25,000 .

Polyacrylamide gel electrophoresis. Disc electrophoresis was done by the methods of Davis ${ }^{15)}$ and $\mathrm{Nagai}^{16}{ }^{16}$ in a column of $5 \%$ polyacrylamide gel with a $\mathrm{pH} 4.0$ buffer system. Electrophoresis was done at a current of $3 \mathrm{~mA}$ per column.

Sodium dodecyl sulfate (SDS) polyacrylamide gel electrophoresis was done by the method of Weber and Osborn. ${ }^{17)}$ Electrophoresis was done at a current of $5 \mathrm{~mA}$ per gel.

Isoelectric focusing. Isoelectric focusing was done by the method of Matsuo ${ }^{18)}$ in a $110-\mathrm{cm}$ column using carrier ampholites, ( $\mathrm{pH} 3-10$, LKB Product AB, Sweden) for $48 \mathrm{hr}$ at $300 \mathrm{~V}$ and $4^{\circ} \mathrm{C}$.

\section{Results and Discussion}

\section{Screening of enzymes having transfer action}

In the screening, transfer activities (TA) and proteolytic activities (PA) of the enzymes were measured. As shown in Table I, we found an enzyme having the largest ratio of TA to PA in the preparation of crude enzyme prepared from S. griseus var. alcalophilus. This is the strain that was screened as a microorganism secreting an alkalophilic proteinase by $\mathrm{T}$. Yamamoto et al. ${ }^{10,11)}$ Therefore, to purify this enzyme, S. griseus var. alcalophilus was cultivated.

\section{Cultivation and purification}

S. griseus var. alcalophilus, donated by Dr. T. Yamamoto was first cultivated with shaking in a medium $(70 \mathrm{ml})$ containing $2 \%$ potato starch, $1 \%$ milk casein, $0.5 \%$ corn steep liquor, $0.3 \% \mathrm{~K}_{2} \mathrm{HPO}_{4}, 0.05 \% \mathrm{MgSO}_{4} \cdot 7 \mathrm{H}_{2} \mathrm{O}$, and $2 \% \mathrm{Na}_{2} \mathrm{CO}_{3}$ at $30^{\circ} \mathrm{C}$ for 3 days. The same 
Table I. Screening of Enzymes Having THE Transfer ACTION

\begin{tabular}{|c|c|c|c|}
\hline Enzymes & $\begin{array}{l}\text { Transfer } \\
\text { activity } \\
(\mathrm{TA})^{a} \\
(\mathrm{U} / \mathrm{ml})\end{array}$ & $\begin{array}{c}\text { Proteolytic } \\
\text { activity } \\
(\text { PA })^{b} \\
(\mathrm{U} / \mathrm{ml})\end{array}$ & $\begin{array}{c}\text { Ratio } \\
\text { of } \\
\text { TA/PA } \\
(\times 10)\end{array}$ \\
\hline $\begin{array}{l}\text { 1. Protease } \\
\text { (Streptomyces griseus } \\
\text { var. alcalophilus) }\end{array}$ & 2.1 & 21 & 1.0 \\
\hline $\begin{array}{l}\text { 2. Prozyme } \\
\text { (Streptomyces } \\
\text { No. 1033) }\end{array}$ & 0.065 & 31 & 0.021 \\
\hline $\begin{array}{l}\text { 3. Actinase E } \\
\text { (Streptomyces } \\
\text { griseus) }\end{array}$ & 0.058 & 65 & 0.009 \\
\hline $\begin{array}{l}\text { 4. Protin } \\
\text { (Bacillus subilis) }\end{array}$ & 1.7 & 60 & 0.28 \\
\hline $\begin{array}{l}\text { 5. Protease } \\
\text { (Bacillus subtilis) }\end{array}$ & 0.50 & 30 & 0.17 \\
\hline $\begin{array}{l}\text { 6. Orientase } \\
\text { (Bacillus subtilis) }\end{array}$ & 3.7 & 240 & $0: 15$ \\
\hline $\begin{array}{l}\text { 7. Protease } \\
\text { (Bacillus subtilis) }\end{array}$ & 0.16 & 16 & 0.10 \\
\hline $\begin{array}{l}\text { 8. Thermoase } \\
\text { (Bacillus subtilis) }\end{array}$ & 0.034 & 200 & 0.0017 \\
\hline $\begin{array}{l}\text { 9. Peptidase } \\
\text { (Aspergillus niger) }\end{array}$ & 0.27 & 65 & 0.042 \\
\hline $\begin{array}{l}\text { 10. Protease } \mathrm{A} \\
\text { (Aspergillus oryzae) }\end{array}$ & 0 & 70 & 0 \\
\hline $\begin{array}{l}\text { 11. Glutase } \\
\text { (Rhizopus } \mathrm{sp} \text { ) }\end{array}$ & 0 & 9 & 0 \\
\hline (Control) & & & \\
\hline 12. Subtilisin BPN' & 2.0 & 110 & 0.18 \\
\hline 13. $\alpha$-Chymotrypsin & 5.1 & 14 & 3.6 \\
\hline 14. Papain & 0.062 & 52 & 0.012 \\
\hline \multicolumn{4}{|c|}{$\begin{array}{l}\text { The transfer activity (TA) was measured as described } \\
\text { in Materials and Methods. } \\
\text { The proteolytic activity (PA) was measured at pH } \\
7.2 \text { and } 30^{\circ} \mathrm{C} \text {, using milk casein as substrate. } \\
\text { azyme manufacturer: } 1,5 \text {, Toyobo; } 2 \text {, Kyowa Hakko; } \\
\text { aken Pharmaceuticals; } 4,8 \text {, Daiwa Chemicals; } 6,7 \text {, } \\
\text { Hankyu Kyoei Bussan; } 9 \text {, Nagase Biochemical; } 10 \text {, } \\
\text { mo Pharmaceuticals; } 12,13,14 \text {, Sigma Chemical. }\end{array}$} \\
\hline
\end{tabular}

medium, freshly autoclaved, was inoculated with $1 \mathrm{ml}$ of the first culture solution (absorbance at $660 \mathrm{~nm}, 9.3$ ) and then, the culture was continued at $30^{\circ} \mathrm{C}$ for 5 days. After centrifugation, the supernatant was used as the starting material for purification.

Step 1. Ammonium sulfate fractionation. The $\mathrm{pH}$ of the supernatant was adjusted to $\mathrm{pH} 7$ by careful addition of acetic acid. To this solution, solid ammonium sulfate was added up to 0.78 saturation. The resulting precipitate was collected by filtration and dissolved in a small amount of $0.05 \mathrm{M}$ acetate buffer ( $\mathrm{pH} 6.0$ ) containing $2 \mathrm{~mm}$ calcium acetate. The solution was dialyzed sufficiently against the same buffer.

Step 2. SP-Sephadex C-50 column chromatography (First). The dialyzed solution was put on a SP-Sephadex C-50 column $(4.4 \times 51 \mathrm{~cm})$, which had been equilibrated with $0.05 \mathrm{M}$ acetate buffer ( $\mathrm{pH} 6.0$ ) containing $2 \mathrm{~mm}$ calcium acetate. The column was washed sufficiently with the same buffer and the proteases were eluted by a linear gradient of ionic strength from 0 to $0.7 \mathrm{M} \mathrm{NaCl}$ (Fig. 1). The fractions (I) from number 133 to 165 were combined and dialyzed against $0.05 \mathrm{M}$ acetate buffer $(\mathrm{pH}$ 6.0 ) containing $2 \mathrm{~mm}$ calcium acetate and $0.1 \mathrm{M}$ $\mathrm{NaCl}$. It was found that fraction I had a strong transfer activity for forming phenylalanine hydroxamic acid (Phe-NHOH), but showed a weak hydrolysis of milk casein. This enzyme was tentatively named "protease I."

On the other hand, it was also observed that about $50 \%$ of the enzymes that had transfer activity forming Phe- $\mathrm{NHOH}$ were not adsorbed on SP-Sephadex C-50 under these conditions. Details will be reported in the future.

Step 3. Sephadex G-75 gel filtration. The dialyzed solution was concentrated by dialysis against polyethylene glycol (\# 20,000). The concentrated solution $(10 \mathrm{ml})$ was put on a Sephadex G-75 column $(3.2 \times 144 \mathrm{~cm})$ that had been equilibrated with $0.05 \mathrm{M}$ acetate buffer (pH 6.0) containing $2 \mathrm{~mm}$ calcium acetate and $0.1 \mathrm{M} \mathrm{NaCl}$. Elution was done with the same buffer, and the active fractions were combined.

Step 4. SP-Sephadex C-50 column chromatography (Second). To remove $\mathrm{NaCl}$, the active fractions were sufficiently dialyzed against 0.05 $\mathrm{M}$ acetate buffer ( $\mathrm{pH} 6.0$ ) containing $2 \mathrm{~mm}$ calcium acetate. The dialyzed solution was put on a SP-Sephadex C-50 column $(3.1 \times 40 \mathrm{~cm})$ that had been equilibrated with $0.05 \mathrm{M}$ acetate buffer ( $\mathrm{pH}$ 6.0) containing $2 \mathrm{~mm}$ calcium acetate. The column was washed sufficiently with 


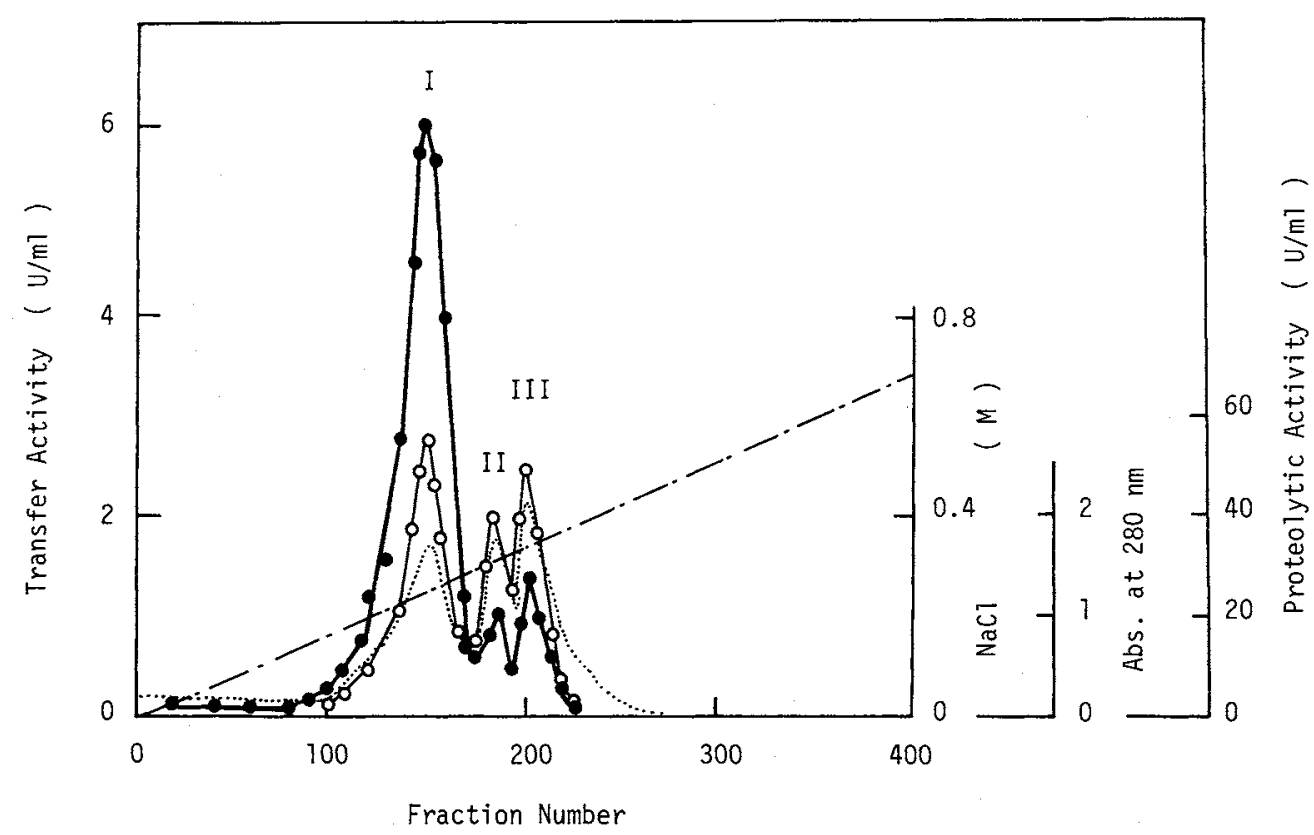

Fig. 1. Elution Pattern of Protease I from S. griseus var. alcalophilus from a SP-Sephadex C-50 Column (First).

Elution was done with a linear gradient of $\mathrm{NaCl}$ at a flow rate of $90 \mathrm{ml} / \mathrm{hr}$. Fractions of $10 \mathrm{ml}$ were collected. - transfer activity; $\bigcirc$, proteolytic activity; --.--, absorbance at $280 \mathrm{~nm} ;---$, concentration of sodium chloride.

Table II. Purification Procedure of Protease I from S. griseus var. alcalophilus.

\begin{tabular}{lcccccc}
\hline Purification steps & $\begin{array}{c}\text { Protein } \\
A_{280}\end{array}$ & $\begin{array}{c}\text { Transfer } \\
\text { activity } \\
\text { (TA) } \\
\text { (U) }\end{array}$ & $\begin{array}{c}\text { Specific } \\
\text { activity } \\
\left.\text { (TA/ } A_{280}\right)\end{array}$ & $\begin{array}{c}\text { Yield } \\
(\%)\end{array}$ & $\begin{array}{c}\text { Proteolytic } \\
\text { activity } \\
\text { (PA) }\end{array}$ & $\begin{array}{c}\text { Ratio } \\
\text { (UA) }\end{array}$ \\
\hline Supernatant fluid of & 117,000 & 3,710 & 0.032 & 100 & 79,300 & 0.047 \\
broth & 19,000 & 3,750 & 0.197 & 101 & 58,900 & 0.064 \\
$\left(\mathrm{NH}_{4}\right)_{2} \mathrm{SO}_{4}$ & 665 & 1,490 & 2.24 & 40 & 16,800 & 0.089 \\
SP-Sephadex C-50 & 234 & 867 & 3.71 & 23 & 7,540 & 0.115 \\
Sephadex G-75 & 154 & 616 & 4.00 & 17 & 5,130 & 0.120 \\
SP-Sephadex C-50 & & & & & & \\
\hline
\end{tabular}

the same buffer and protease I was eluted by a linear gradient of ionic strength from 0 to $0.5 \mathrm{M}$ $\mathrm{NaCl}$. The active fractions were combined and used as the purified enzyme preparation. This preparation was purified about 125-fold from the culture broth and the specific activity of transfer action was 4.0 units/Abs. at $280 \mathrm{~nm}$. This purified enzyme was used in the following experiments. The results of the purification procedures are summarized in Table II.
Homogeneity of the purified enzyme preparation and isoelectric point measurement

Homogeneity of the purified enzyme preparation was tested by disc electrophoresis on polyacrylamide gels. The enzyme preparation was found to be homogeneous electrophoretically. The isoelectric focusing test found that the isoelectric point of the enzyme was 8.4.

\section{Molecular weight}

The molecular weight of protease I was esti- 
mated by gel filtration and SDS-polyacrylamide gel electrophoresis. A column of Sephadex $\mathrm{G}-75(1.76 \times 76 \mathrm{~cm})$ eluted with $0.05 \mathrm{M}$ acetate buffer ( $\mathrm{pH}$ 6.0) containing $2 \mathrm{~mm}$ calcium acetate and $0.1 \mathrm{M} \mathrm{NaCl}$ was used. The molecular weight of the enzyme was estimated to be 25,000 by gel filtration, using bovine serum albumin, ovalbumin, chymotrypsinogen $\mathrm{A}$, and ribonuclease $\mathrm{A}$ as standard proteins. This value is distinct from that of alkalophilic proteinase $\left(M_{w}=50,000\right) .^{10)}$

On SDS polyacrylamide gel electrophoresis, the enzyme preparation showed a single band. The molecular weight of the enzyme was estimated to be 28,000 from the mobility on SDS polyacrylamide gel electrophoresis, using $\alpha_{2^{-}}$ macroglobulin (reduced type), phosphorylase b, glutamate dehydrogenase, lactate dehydrogenase, and soybean trypsin inhibitor as standard proteins.

\section{Effects of $\mathrm{pH}$ and temperature on stability and activity}

Protease I was stable from $\mathrm{pH} 5.0$ to 10.0 at $40^{\circ} \mathrm{C}$ for $1 \mathrm{hr}$, as shown in Fig. 2. Using casein as substrate, the optimum $\mathrm{pH}$ for the proteolytic reaction was 11.0 , which is distinct from that of alkalophilic proteinase (Opt. $\mathrm{pH}$ at

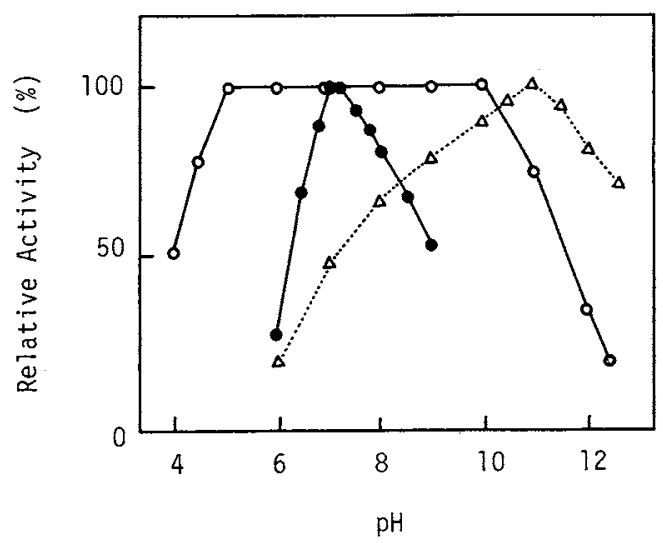

Fig. 2. Effects of pH on Activity and Stability of Protease I from $S$. griseus var. alcalophilus.

The transfer activity $(\odot$, TA) and proteolytic activity $(\triangle$, PA) of the enzyme were assayed at the indicated $\mathrm{pH}$. The stability $(O)$ of the enzyme was measured by assaying the residual activities (TA and $\mathrm{PA}$ ) after incubation at the indicated $\mathrm{pH}$ and $40^{\circ} \mathrm{C}$ for $1 \mathrm{hr}$.
12.3 or higher). ${ }^{10)}$ On the other hand, protease I was most active from $\mathrm{pH} 7.0$ to 7.2 in the transfer reaction forming phenylalanine hydroxamic acid (Phe-NHOH).

The enzyme was stable at temperature below $50^{\circ} \mathrm{C}$ at $\mathrm{pH} 6.0$ for $15 \mathrm{~min}$. The optimum temperature for the transfer reaction of the enzyme was $55^{\circ} \mathrm{C}$.

\section{Effects of various chemicals}

In the study of the effects of inhibitors and metal ions, $1 \mathrm{ml}$ of $1.06 \times 10^{-5} \mathrm{M}$ enzyme solution was incubated with $1 \mathrm{ml}$ of each inhibitor

Table III. EFfects of Chemical Rfagents on PrOTEASE I FROM S. griseus var. alcalophilus

\begin{tabular}{|c|c|c|}
\hline Reagent & $\begin{array}{l}\text { Concentration } \\
(\mathrm{mM})\end{array}$ & $\begin{array}{c}\text { Relative activity } \\
(\%)\end{array}$ \\
\hline None & & 100 \\
\hline \multirow[t]{2}{*}{ DFP } & 1 & 5 \\
\hline & 2 & 0 \\
\hline Chloroquine & 1 & 94 \\
\hline MIA & 1 & 94 \\
\hline PCMB & 1 & 100 \\
\hline DTT & 1 & 97 \\
\hline $\mathrm{DAN}^{a}$ & 4.4 & 94 \\
\hline $\mathrm{EPNP}^{b}$ & $(10 \mathrm{mg} / \mathrm{ml})$ & 96 \\
\hline EDTA & 10 & 97 \\
\hline$o$-Phenanthroline & 1 & 98 \\
\hline N-Ethylmaleimide & 1 & 94 \\
\hline $\mathrm{BaCl}_{2}$ & 1 & 103 \\
\hline $\mathrm{CaCl}_{2}$ & 1 & 104 \\
\hline $\mathrm{CdCl}_{2}$ & 1 & 98 \\
\hline $\mathrm{CoCl}_{2}$ & 1 & 99 \\
\hline $\mathrm{CuCl}_{2}$ & 1 & 85 \\
\hline $\mathrm{FeCl}_{3}$ & 1 & 93 \\
\hline $\mathrm{HgCl}_{2}$ & 1 & 81 \\
\hline $\mathrm{MgCl}_{2}$ & 1 & 94 \\
\hline $\mathrm{MnCl}_{2}$ & 1 & 103 \\
\hline $\mathrm{NiCl}_{2}$ & 1 & 105 \\
\hline $\mathrm{SrCl}_{2}$ & 1 & 100 \\
\hline $\mathrm{ZnCl}_{2}$ & 1 & 94 \\
\hline
\end{tabular}

a The reaction was done at $14^{\circ} \mathrm{C}$ and $\mathrm{pH} 6.0$ for $1 \mathrm{hr}$ by the method of Rajagopalan et al. ${ }^{19)}$

$b$ The reaction was done with $1 \mathrm{ml}$ of $5.3 \times 10^{-6} \mathrm{M}$ enzyme solution and $10 \mathrm{mg}$ of solid EPNP powder at $25^{\circ} \mathrm{C}$ and $\mathrm{pH} 6.0$ for $72 \mathrm{hr}$ by the method of Tang. ${ }^{20)}$

DFP, diisopropylfluorophosphate; MIA, monoiodoacetate; PCMB, p-chloromercuribenzoate; DTT, dithiothreitol; DAN, diazoacetyl-DL-norleucine methyl ester; EPNP, 1,2-epoxy-3-(p-nitrophenoxy) propane; EDTA, disodium ethylenediamine tetraacetate. 
at $30^{\circ} \mathrm{C}$ for $15 \mathrm{~min}$, and with each metal ion at $40^{\circ} \mathrm{C}$ for $30 \mathrm{~min}$ in $0.05 \mathrm{M}$ acetate buffer $(\mathrm{pH}$ 6.0 ). Then enzyme activity was measured as described in Materials and Methods. As shown in Table III, protease I was markedly inhibited by DFP, which is a typical inhibitor of serine proteinases. However, the enzyme was not inhibited by reagents that attack sulfhydryl residues of proteins such as MIA, PCMB, and $\mathrm{N}$-ethylmaleimide. And the chelators and the inhibitors of aspartic proteinase such as DAN and EPNP did not cause inhibition. From these results, it is considered that protease $I$ is a serine proteinase.

Most of metal ions had no effect on this enzyme, although $\mathrm{Hg}^{2+}$ inhibited the enzyme activity by about $20 \%$.

\section{Hydrolysis of peptides and amino acid esters by protease I}

To examine the substrate specificity in the hydrolytic reaction, the enzyme was incubated with each substrate at the indicated concentration. The results indicate that protease I strongly hydrolyzed poly-Lys, Leu-Leu-Leu, and Phe-OEt, and weakly the peptides (or amino acid esters) containing acidic amino acids such as poly-Glu, Cbz-Glu-Tyr, Asp-diOBzl, and Glu-di-OEt, as shown in Table IV and V. Besides, the enzyme hydrolyzed the peptides (or amino acid esters) containing small aliphatic amino acids such as Gly, Ala, and Ser. However, it was not active on peptides containing D-amino acids or $y$-Glu or on various $\mathrm{N}$ - and $\mathrm{C}$-unprotected dipeptides. From this study, it can be considered that protease $I$ is an enzyme having broad substrate specificity, although the affinity for amino acids such as Phe, Leu, Lys. Glu, Ala, and Gly may be different.

Interestingly, protease I hydrolyzed Phe-OEt, Gly-Gly-Phe, Cbz-Ala-Leu-NH ${ }_{2}$, Cbz-ProLeu- $\mathrm{NH}_{2}$, and Cbz-Gly-Leu- $\mathrm{NH}_{2}$, although the alkalophilic proteinase ${ }^{10)}$ was not active

Table IV. Hydrolytic Action of Protease I on Various Synthetic Peptides

Relative activities of the enzyme against each substrate were measured by the ninhydrin method of Yemm and Cocking. ${ }^{12)}$ The rate of L-Leu-L-Leu-L-Leu was taken as 100.

\begin{tabular}{|c|c|c|c|c|c|}
\hline Peptide & $\begin{array}{l}\text { Concentration } \\
(\mathrm{mm})\end{array}$ & $\begin{array}{l}\text { Relative } \\
\text { activity }\end{array}$ & Peptide & $\begin{array}{c}\text { Concentration } \\
(\mathrm{mM})\end{array}$ & $\begin{array}{l}\text { Relative } \\
\text { activity }\end{array}$ \\
\hline Leu-Leu-Leu & 10 & 100 & Gly-Gly & 25 & 0 \\
\hline Gly-Gly $\downarrow$ Phe & 10 & 27 & Gly-Leu & 25 & 0 \\
\hline Gly-Phe $\leftleftarrows$ Phe & 10 & 38 & Gly-Phe & 25 & 0 \\
\hline Phe-Phe-Phe & 10 & 45 & Gly-Pro & 25 & 0 \\
\hline Ala-Ala-Ala & 10 & 22 & Gly-Tyr & 25 & 0 \\
\hline Gly-Gly-Gly & 17 & 0 & Leu-Gly & 25 & 0 \\
\hline Ala-Gly-Gly & 17 & 0 & Leu-Phe & 12 & 0 \\
\hline Leu-Gly-Gly & 17 & 0 & Leu-Trp & 12 & 0 \\
\hline$\gamma$-Glu-Cys-Gly & 10 & 0 & Glu-Glu & 12 & 0 \\
\hline Cbz-Glu ${ }^{\downarrow}$ Tyr & 1 & 8 & Lys-Lys & 12 & 0 \\
\hline $\mathrm{Cbz}-\mathrm{Tyr} \stackrel{\downarrow}{ } \mathrm{Gly}^{\downarrow} \stackrel{\mathrm{NH}_{2}}{ }$ & 1 & 57 & polÿ-Lys & $(0.5 \%)$ & 351 \\
\hline Cbz-Gly $\stackrel{\downarrow}{\mathrm{T} y \mathrm{r}} \stackrel{\downarrow}{\mathrm{N}} \mathrm{NH}_{2}$ & 1 & 21 & poly-Glu & $(0.5 \%)$ & 7 \\
\hline Cbz-Ala-Leu- ${ }^{\downarrow} H_{2}$ & 1 & 48 & & & \\
\hline Cbz-Pro-Leu $₫ \mathrm{NH}_{2}$ & 1 & 32 & & & \\
\hline Cbz-Gly-Leu $\stackrel{\mathrm{NH}_{2}}{ }$ & 1 & 26 & & & \\
\hline $\mathrm{Cbz}$-Gly-D-Leu- $\mathrm{NH}_{2}$ & 10 & 0 & & & \\
\hline
\end{tabular}

The hydrolytic products were identified by thin layer chromatography. The arrows show the bonds split. Cbz, carbobenzoxy. 
on them. From the substrate specificity results, it was also proved that protease I was distinct from the alkalophilic proteinase reported previously. ${ }^{103}$

Table V. Hydrolytic Action of Protease I ON VARIOUS AMINo ACID Esters

The final concentration of the substrate was $0.1 \mathrm{M}$, except for $0.04 \mathrm{M}$ Asp-di-OBzl. The rate of L-Phe-OEt was taken as 100 .

\begin{tabular}{|c|c|}
\hline Ester & Relative activity \\
\hline Phe-OEt & 100 \\
\hline Leu-OEt & 39 \\
\hline Val-OMe & 6 \\
\hline Ser-OMe & 12 \\
\hline Gly-OEt & 4 \\
\hline Asp-di-OBzl* ${ }^{*}$ & 15 \\
\hline Glu-di-OEt & 10 \\
\hline Glu- $\gamma$-OMe & 0 \\
\hline Arg-OMe & 12 \\
\hline Lys-OEt & 25 \\
\hline
\end{tabular}

* Dimethyl sulfoxide $(25 \%)$ was contained in the reaction mixture.

-OBzl, benzyloxy.
Formation of hydroxamic acids by protease I

To identify the donor specificity in the transfer reaction, the enzyme reaction was done with various esters as donors. One-tenth of a milliliter of $1.5 \times 10^{-5} \mathrm{M}$ enzyme solution was incubated with $0.3 \mathrm{ml}$ of a mixture containing each ester and hydroxylamine in $75 \mathrm{~mm}$ phosphate buffer ( $\mathrm{pH} 7.0$ ). After incubation for 10 min at $40^{\circ} \mathrm{C}$, the amounts of hydroxamic acids synthesized were measured by the methods described in Materials and Methods. Table VI shows the relative rates of formation of various hydroxamic acids by protease I. This enzyme catalyzed the transfer reaction forming hydroxamic acids of various amino acids such as Tyr, Phe, Leu, Arg, Lys, Asp, Glu, Ala, and Gly, although the rates for each transfer reaction were different. However, it was not active on Glu- $\gamma$-OMe and Ac-Pro-OMe. From the above results, it was found that protease I had a broad donor specificity in the transfer reaction synthesizing hydroxamic acid.

There are several proteases that catalyze transpeptidation reactions, ${ }^{21-23)}$ for example,

Table VI. Formation of Various Hydroxamic Acids by the Transfer Action of PROTEASE I FROM S. griseus var. alcalophilus

The reaction was done at $40^{\circ} \mathrm{C}$ and $\mathrm{pH} 7.0$, using various esters (donors) containing $0.5 \mathrm{M} \mathrm{NH}_{2} \mathrm{OH}$ as substrates. The rate of L-Phe-OEt was taken as 100 .

\begin{tabular}{lcclrr}
\hline Donor & $\begin{array}{c}\text { Concentration } \\
(\mathrm{M})\end{array}$ & $\begin{array}{c}\text { Relative } \\
\text { activity }\end{array}$ & Donor & $\begin{array}{c}\text { Concentration } \\
(\mathrm{M})\end{array}$ & $\begin{array}{c}\text { Relative } \\
\text { activity }\end{array}$ \\
\hline Phe-OEt & 0.1 & 100 & Ac-Phe-OEt* & 0.04 & 112 \\
Phe-OMe & 0.1 & 170 & Ac-Tyr-OEt* & 0.1 & 267 \\
Tyr-OEt & 0.1 & 297 & Ac-Val-OMe & 0.1 & 23 \\
Leu-OEt & 0.1 & 127 & Ac-Leu-OMe* & 0.1 & 299 \\
Val-OMe & 0.1 & 10 & Ac-Arg-OMe & 0.1 & 37 \\
Arg-OMe & 0.1 & 6 & Ac-Lys-OMe & 0.1 & 90 \\
Arg(NO, $)_{-O B z 1^{*}}$ & 0.1 & 21 & Ac-Asp-OMe & 0.1 & 43 \\
Lys-OEt & 0.1 & 13 & Ac-Glu- $\alpha$-OMe* & 0.05 & 165 \\
Asp-di-OBzl & 0.04 & 76 & Ac-Pro-OMe & 0.1 & 0 \\
Glu- $\alpha-O B z 1^{*}$ & 0.025 & 66 & Bz-Arg-OEt & 0.1 & 13 \\
Glu-di-OBzl & 0.04 & 37 & Bz-Lys-OMe* & 0.1 & 27 \\
Glu-di-OEt & 0.1 & 23 & Bz-Ala-OMe* & 0.1 & 29 \\
Glu- $\gamma$-OMe & 0.1 & 0 & Bz-Gly-OEt* & 0.1 & 14 \\
Ser-OMe & 0.1 & 20 & Ac-Gly-Lys-OMe & 0.1 & 43 \\
Gly-OEt & 0.1 & 7 & Cbz-Val-Phe-OMe* & 0.02 & 22 \\
Asp-Phe-OMe* & 0.033 & 11 & Cbz-Phe-Leu-OMe* & 0.02 & 7 \\
& & & Cbz-Ser-Leu-OMe* & 0.03 & 88
\end{tabular}

* Dimethyl sulfoxide ( $25 \%$ ) was contained in the reaction mixture.

$\mathrm{Ac}$, acetyl; $\mathrm{Bz}$, benzoyl; $\mathrm{Cbz}$, carbobenzoxy; -OEt, ethoxy; -OMe, methoxy; -OBzl, benzyloxy. 
$\alpha$-chymotrypsin, trypsin, papain, and cathepsin C. However, it is actually difficult to synthesize various peptides by a single protease, because the proteases so far reported have narrow substrate specificities. This study shows that protease I from $S$. griseus var. alcalophilus is a unique enzyme having broad donor specificity in transfer reactions and forming various hydroxamic acids from esters and hydroxylamine, and that is distinct from the alkalophilic proteinase reported previously. ${ }^{10)}$ It also suggests the utility of this enzyme for the synthesis of various peptides. At present we are investigating the acceptor specificity of protease I.

Acknowledgments. The authors are indebted to Dr. T. Yamamoto, Faculty of Engineering, Fukuyama University, for valuable advice and encouragement. The authors wish to express their thanks to Miss. M. Ueno, Industrial Technology Center of Fukui Prefecture, for her help in a part of this study.

\section{References}

1) M. Bergmann and H. Fraenkel-Conrat, J. Biol. Chem., 119, 707 (1937).

2) M. Bergmann and J. S. Fruton, J. Biol. Chem., 124, 321 (1938).

3) K. Inouye, K. Watanabe, K. Morihara, Y. Tochino, T. Kanaya, J. Emura and S. Sakakibara, J. Am. Chem. Soc., 101, 751 (1979).

4) K. Morihara, T. Oka and H. Tsuzuki, Nature, 280, 412 (1979).

5) K. Morihara, T. Oka, H. Tsuzuki, Y. Tochino and
T. Kanaya, Biochem. Biophys. Res. Commun., 92, 396 (1980)

6) Y. Isowa, M. Ohmori, M. Sato and K. Mori, Bull. Chem. Soc. Jpn., 50, 2766 (1977).

7) M. Fujimaki, H. Kato, S. Arai and M. Yamashita, J. Appl. Bact., 34, 119 (1971).

8) R. Saltman, D. Vlach and P. L. Luisi, Biopolymers, 16, 631 (1977).

9) J. K. McDonald, B. B. Zeitman, T. J. Reilly and S. Ellis, J. Biol. Chem., 244, 2693 (1969).

10) T. Nakanishi, Y. Matsumura, N. Minamiura and T. Yamamoto, Agric. Biol. Chem., 38, 37 (1974).

11) T. Yamamoto, Japan Kokai Tokkyo Koho, 79, 11,396 (May 15, 1979).

12) E. M. Yemm and E. C. Cocking, Analyst., 80, 209 (1955).

13) P. S. Roberts, J. Biol. Chem., 232, 285 (1958).

14) R. F. Snell and C. T. Snell, "Colorimetric Methods of Analysis," Vol. II, 3rd Ed., Van Nostrand, New York, 1949 , p. 818

15) B. J. Davis, Ann. N.Y. Acad. Sci., 121, 404 (1964).

16) Y. Nagai, Protein, Nucleic Acid and Enzyme, Bessatsu, IX, 3 (1967).

17) K. Weber and M. Osborn, J. Biol. Chem., 244, 4406 (1969).

18) Y. Matsuo and T. Horio, Protein, Nucleic Acid and Enzyme, 12, 737 (1967).

19) T. G. Rajagopalan, W. H. Stein and S. Moore, J. Biol. Chem., 241, 4295 (1966).

20) J. Tang, J. Biol. Chem., 246, 4510 (1971).

21) J. S. Fruton, W. R. Hearn, V. W. Ingrain, D. S Wiggans and M. Winitz, J. Biol. Chem., 204, 891 (1953).

22) K. Morihara and T. Oka, Kagaku no Ryoiki, 36, 444 (1982).

23) K. Morihara, Trends in Biotechnology, 5, 164 (1987). 